\title{
UNUSUAL TYPES OF LAYERED ORGANIC CRYSTAL HYDRATES
}

\author{
A.M.Banaru, E.S.Mammadov* \\ Moscow State University, Chemistry Faculty \\ *Baku Branch of Moscow State University, Chemistry Faculty \\ banaru@mail.ru \\ Eyyub-84@mail.ru
}

Received 27.01.2021

Accepted 11.02.2021

\begin{abstract}
In molecular crystalline hydrates with a high content of crystallization water infinite $\mathrm{H}_{2} \mathrm{O}$... $\mathrm{OH}_{2}$ nets or finite fragments of such nets are formed. As a rule, these nets contain 5- and 6-membered cycles $\left(\mathrm{H}_{2} \mathrm{O}\right)_{n}$. Brand new topological types of layered organic crystal hydrates among the structures included in the Cambridge Structural Database in 2009-2019 were found and investigated. The discovered nets were deposited to the Topological Types Database. Topological characteristics of new nets are described, in particular, the maximum possible symmetry, information indices, vertex, edge and face transitivity of the nets.
\end{abstract}

Keywords: crystal hydrate, topology, complexity, H-bond, net, clathrate, crystal structure, X-ray crystallography, molecular agglomerate, symmetry, Cairo tiling, data mining.

doi

The undying interest in organic crystal hydrates in recent decades arises from the fact that organic medicines are often produced as hydrates, and in some countries each new crystal modification of the bioactive substance (polymorph, hydrate, solvate) can be patented separately. According to some estimates [1], crystal hydrates account for up to $40 \%$ of all forms of organic substances for which different modifications are known. Compared to a pure substance, crystal hydrates often have better water solubility [2] and, consequently, better bioavailability. Attempts are being made to predict whether the substance will crystallize as a hydrate, and what kind of hydrate is likely to be formed. Predictions are divided into two groups: 1) by computer modelling methods, for example, finding the minimal potential energy of a hypothetical crystal hydrate [3] and the method of molecular dynamics [4];2) by statistical methods of processing structural data, first of all, from the Cambridge Structural Database (CSD).

As the molecular dynamic calculation has shown [5], when the pure water is being frozen at mild conditions, the concentration of 6-membered rings near the interphase boundary gradually grows, at the same time, the concentration of 5- and 7-membered rings abruptly reaches its maximum. In liquid water there are also 4- and 8-membered rings (Figure 1 ), but their life time is much shorter. In the crystal structures of organic hydrates all these rings, from 4- to 8-membered, are found [6].

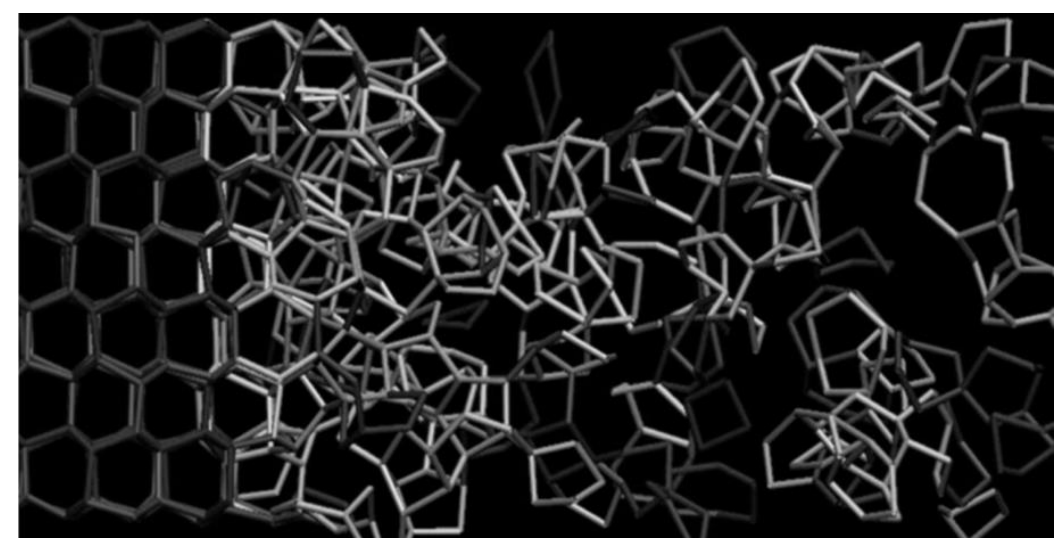

Fig. 1. An instantaneous ring configuration during the growth of hexagonal ice $\mathrm{I} h[6]$. 
Crystal hydrates of organic molecules of relatively small size with hydrophilic functional groups often have a layered structure $[7,8]$. The layers composed of hydrophobic parts of an organic molecule alternate with $\mathrm{H}$-bonds $\mathrm{H}_{2} \mathrm{O} \ldots \mathrm{OH}_{2}$, in which hydrophilic groups of organic molecules are also involved. Nets $\left(\mathrm{H}_{2} \mathrm{O}\right)_{\infty}$ are commonly corrugated fragments of clathrate hydrate framework, for example, fragments of dodecahedral cavity $5^{12}$ or truncated octahedral cavity $4^{6} 6^{8}$ [9]. Despite being corrugated, these nets are usually planar and can be embedded in 2D space without crossing the edges. In particular, the water layer made of fragments $5^{12}$, when projected onto a plane, gives the so-called Cairo tiling [10], one of the [11] Laves nets, which divide the plane into identical polygons. This topology is realized in the crystal structure of ice XII [11] being formed under the pressure of $1 \mathrm{GPa}$ and having disordered protons (Figure 2). Many infinite 2D nets, also found in MOFs, are listed in the Reticular Chemistry Structure Resource (RCSR) [12], with Cairo tiling having refcode mcm. Many more nets, including those predicted theoretically, can be found in topcryst database [13].

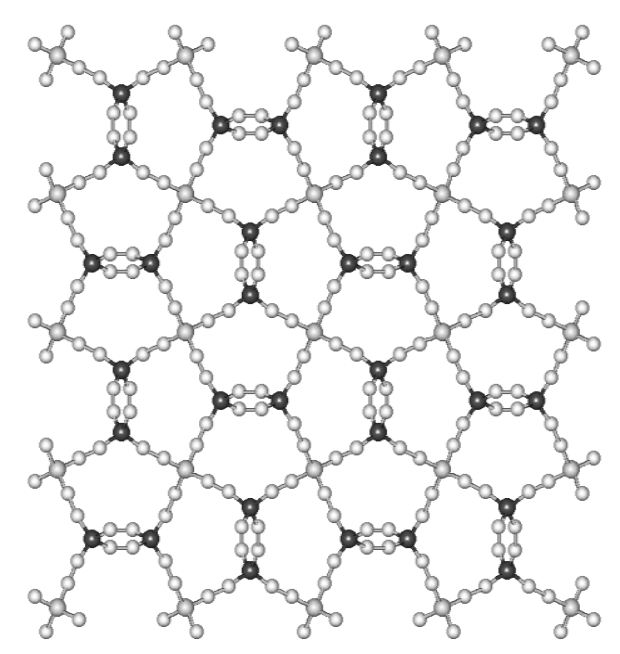

Fig. 2. A fragment of Cairo tiling in the crystal structure of ice XII.

Several important conclusions about the structure of organic crystal hydrates were made based on statistical data [7].
Firstly, the frequency of hydrate formation increases as the total number of $\mathrm{H}$-donor and $\mathrm{H}$-acceptor groups in a molecule increases. Secondly, with the growth of the total "valence" of a molecule with respect to $\mathrm{H}$-bonds the average number of symmetrically independent molecules $\mathrm{H}_{2} \mathrm{O}$ increases. Practically, this means forming less regular aqueous nets. If a molecule has polar groups all over its outer surface (such as, for example, in cyclodextrins and cucurbiturils), then infinite aqueous nets cannot form, giving way just to finite associates [9]. Thirdly, molecules $\mathrm{H}_{2} \mathrm{O}$ are coordinated by $\mathrm{H}$-bonds in a different manner with different frequencies. In more than half cases $\mathrm{H}_{2} \mathrm{O}$ is 3-coordinated, and generally it forms two $\mathrm{H}$ bonds as a donor (D) and one H-bond as an acceptor (A) of a proton (DDA) [7]. In total, the portion of water molecules saturating both H-donor "valencies" (DDA, DDAA, DD and multicentre DDDA and DDDAA) is about $85 \%$. This condition causes hydrate composition relation with the "valence" of water molecules [14, 15]. If a hydrate has $n \mathrm{H}_{2} \mathrm{O}$ per organic molecule, the average number of protons in a water molecule that is redundant for the aqueous $\mathrm{H}$-associate is called protic excess and is usually multiple of $1 / n$. Protic excess is univocally expresses via the average size of water cycles that are not the sum of smaller cycles (in topology such cycles are called strong rings [16]). For example, at the average size 5 the protic excess is $1 / 3$, for this reason such nets are found mainly in three- and hexahydrates [14]. It has been confirmed by many crystal structures discovered in recent years, for example, by the structure of 3-pyrroline trihydrate [17]. The most layers and tapes $\left(\mathrm{H}_{2} \mathrm{O}\right)_{\infty}$ are characterized by complete $\mathrm{H}$-acceptor stabilization by groups of organic molecule. As the size of an aqueous associate decreeses, the portion of structures with incomplete $\mathrm{H}$-acceptor stabilization increases, i.e., the greater the number of excess protons, the less likely they are to be saturated by $\mathrm{H}$-bonds. Aqueous associates with small values of 
protic excess (first of all, layers) are stabilized mainly by $\mathrm{N}$-containing $\mathrm{H}$-acceptors of organic molecule (amino groups, pyridyl, Noxides etc.). As the protic excess increases, the portion of associates stabilized by $\mathrm{O}$ containing $\mathrm{H}$-acceptors (groups $\mathrm{OH}, \mathrm{C}=\mathrm{O}$, COO-etc.) increases.

The aim of this work was a metaanalysis of crystal structures of layered molecular crystalline hydrates, whose structure was determined in the last decade, and the identification of new topological types, if any.

\section{Method}

The search for layered crystal hydrates was carried out in CSD version 5.39 (updates till Nov. 2019). The main search criterion was the presence of a water molecule forming four $\mathrm{H}$-bonds with other water molecules (distance O...O should not exceed $3.04 \AA$ ). Over the last decade, more than 100 such structures have been deposited to CSD. The choice of this time interval is based on the year of publication (2010) of the last detailed study of layered hydrates [14]. Topological analysis was carried out using Topos Pro [18]. For the layered associate $\left(\mathrm{H}_{2} \mathrm{O}\right)_{\infty}$ graph with the vertices corresponding to atoms $\mathrm{O}$ and the edges corresponding to $\mathrm{H}$-bonds was constructed. If the associate included atoms $\mathrm{O}$ of the organic molecule (e.g., carbonyl) and if in their absence the dimensionality of the associates decreases, then these atoms were considered together with atoms $\mathrm{O}$ of water molecules. The distinction of topological types was examined using TTD (Topological Types Database) [18] and topCryst [13]. The nets of previously unknown topological type were analyzed using Gavrog software package [19]. To find the most symmetric embedding of a net, Gavrog uses barycentric placement in which each vertex of the net is placed into the centre of gravity of its adjacent vertices (all vertices have the same weight). The resulting net is called stable if no two vertices collide. Stable nets have the maximum achievable crystallographic symmetry [20]. If one considers the net to be a system of harmonic oscillators (the egdes), the smallest normalized potential energy of this system is achieved for the barycentric placement [21]:

$$
E=V^{-2 / d} \Sigma_{e \in E_{0}}\|v(e)\|^{2}
$$

where $V$ is the volume of the unit cell of $d$ dimensional lattice, $\left\{v(e) \mid e \in E_{0}\right\}$ is the system of vectors of the oriented quotient graph of the net. The net can be mapped onto a finite graph, called quotient graph, where each vertex lattice is mapped onto one vertex and each edge lattice is mapped onto one edge. The quotient graph, like any finite graph, is characterized by the cyclomatic number - the largest number of edges that can be removed from the graph to keep it connected. The most symmetric embedding of a net has the smallest possible transitivity $p, q, \mathrm{r}$ (the number of non-equivalent vertices, edges and faces).

The Motherwell symbol and the vertex symbol are used to classify layers $\left(\mathrm{H}_{2} \mathrm{O}\right)_{\infty}$. According to Motherwell [8], infinite layers are denoted $\operatorname{Lm}_{1}\left(n_{1}\right) m_{2}\left(n_{2}\right) \ldots m_{k}\left(n_{k}\right)$, where $m_{1}, m_{2}, \ldots, m_{k}$ are the sizes of non-intersecting rings in the layer, and $n_{i}$ is the total number of rings having at least one common vertex with the given one. For example, Cairo tiling has the symbol L5(7). The vertex symbol is constructed in a following way [22]: for each vertex, the adjacent polygons are listed in the clockwise direction starting from the smallest one. In Cairo tiling there are two non-equivalent vertices, 3- and 4coordinated, with the ratio 2:1 (Figure 2). The full vertex symbol is $\left(5^{3}\right)_{2}\left(5^{4}\right)$.

Information indices characterizing the complexity of a net were calculated in ToposPro before and after optimization in Gavrog. According to Krivovichev [23],

$$
\begin{gathered}
I_{G}=-\sum p_{i} \log _{2} p_{i}\left(\frac{\text { bits }}{\text { atom }}\right), \\
I_{G, n}=I_{G} / I_{G, \max }, \\
I_{G, \max }=\log _{2} v\left(\frac{\text { bits }}{\text { atom }}\right),
\end{gathered}
$$

where $I_{G}$ is information entropy per atom, $I_{G, n}-$ normalized information entropy per atom, $p_{i}=v_{i} / v, v_{i}-$ number of atoms occu- 
pying the $i$-th system of equivalent positions (orbit); $v$ - total number of atoms in the reduced unit cell. Only atoms $\mathrm{O}$ were considered as vertices. For example, Cairo tiling contains 6 vertices in the reduced unit cell: two 4-coordinated equivalent vertices, and four 3-coordinated ones. Therefore, $I_{G}=-$ $1 / 3 \cdot \log _{2} 1 / 3-2 / 3 \cdot \log _{2} 2 / 3=0.918$ and $I_{G, n}=$ $0.918 / \log _{2} 6=0.355$.

\section{Results and Discussion}

The first time the Cairo tiling was found in a layered organic hydrate was in 1968 for the crystal structure of piperazine hexahydrate [24]. Of course, the actual configuration of $\mathrm{H}$ bonds $\mathrm{H}_{2} \mathrm{O} \ldots \mathrm{OH}_{2}$ in this net implies a wavy layer projected onto a planar graph. Other common topological types of layered crystal hydrates also have a certain thickness and display just a virtual planarity. Only three structures in CSD (2009-2019) contain layers $\left(\mathrm{H}_{2} \mathrm{O}\right)_{\infty}$ with the topology being not mentioned in any of the existing databases (Table 1). The detected topological types were deposited to TTD, where they were assigned codes 3,3,3,4L78, 3,3,3,3,4,4L41 and $3,3,3,3,3,3,3,3,4 \mathrm{~L} 9$. This code lists the coordination of non-equivalent vertices and the ordinal number of the net among nets with the same coordination included in TTD. Thus, TTD already contains 77, 40 and 8 similar topological types, respectively. The cyclomatic number of their quotient graph is 11,17 and 11, respectively. According to the theorem proved by Beukemann and Klee [25], a finite graph is the quotient graph of $p$-periodic net $(p \geq 2)$ if and only if it con- nected, at least 3-coordinated and its cyclomatic number is $p$. Thus, all the considered nets have more than 10-period embedding in Euclidian space of the corresponding dimensionality indicating a very complex arrangement. As it was shown in previous short communication [26], information indices for such unusual topologies are higher than those for more common water layers among the structures of CSD.

None of the $\mathrm{H}$-associates was discussed in original articles. The first article is entirely devoted to organic synthesis and $\mathrm{X}$ ray structure determination was performed just to illustrate the molecular structure of the target product (refcode EHUJEY [27]). The second article has been published in the journal on medicinal chemistry and is devoted to the synthesis of drugs to treat leukemia, for which one of molecular structures (SAXDON [28]) has been studied. In the third work, the crystallized substance was not a target product but a ligand (FELRIA [29]) used for the synthesis of the complex of $\mathrm{Zn}^{2+}$. In this article "hydrophilic channels formed by $\mathrm{H}$-bonded lattice water molecules interlinked by tetrameric, pentameric and hexameric cyclic H-bonds" are mentioned without discussion in detail. The crystal structures of EHUJEY, FELRIA and SAXDON contain 4, 6 and 11 symmetrically independent $\mathrm{H}_{2} \mathrm{O}$ molecules. In EHUJEY and FELRIA all water molecules are involved in $\left(\mathrm{H}_{2} \mathrm{O}\right)_{\infty}$, while in SAXDON 2 of 11 molecules are not involved and form $\mathrm{H}$ bonds with the organic molecule separately.

Layered $\mathrm{H}$-associates $\left(\mathrm{H}_{2} \mathrm{O}\right)_{\infty}$ of previously unknown topological types in CSD compared with the Cairo tiling

\begin{tabular}{|c|c|c|c|c|}
\hline Average ring size & 5.0 & 5.0 & 5.2 & 5.6 \\
\hline Vertex symbol & $\left(5^{3}\right)_{2}\left(5^{4}\right)$ & $(4.5 .6)\left(4.5^{2} .6\right)\left(5^{2} .6\right)\left(5^{3}\right)_{2}\left(5^{4}\right)$ & $\left(5^{2} .6\right)_{2}\left(5^{3} .6\right)\left(5^{3}\right)$ & $(4.6 .5 .6)(4.5 .6)(5.6 .8)_{2}\left(5.6^{2}\right)_{2}\left(5^{2} .6\right)\left(5^{2} .8\right)\left(6^{2} .8\right)$ \\
\hline Motherwell symbol & $\mathrm{L} 5(7)$ & $\mathrm{L} 4(6) 5(7)^{6} 6(8)$ & $\mathrm{L} 5(6)^{2} 5(7)^{2} 6(8)$ & $\left.\mathrm{L} 4(6) 5(5)^{2} 5(6)^{2} 6(6) 6(7)\right)^{2} 6(8) 8(8)$ \\
\hline Maximum symmetry & $p 4 g m$ & $p g g 2$ & $p g g 2$ & $p 2$ \\
\hline Transitivity & $2,2,1$ & $6,10,5$ & $4,7,3$ & $9,14,7$ \\
\hline Cyclomatic number & 5 & 17 & 2.000 & 3.170 \\
\hline$I_{G}$ (bits/atom) & 0.918 & 2.585 & 0.500 & 0.760 \\
\hline$I_{G, n}$ & 0.355 & 0.564 & EHUJEY & SAXDON \\
\hline $\begin{array}{c}\text { Observed first in } \\
\text { (refcode) }\end{array}$ & PIPERH & FELRIA & 2020 & 2020 \\
\hline Detected in (year) & 1968 & 2020 & $3,3,3,4 \mathrm{~L} 78$ & $3,3,3,3,3,3,3,3,4 \mathrm{~L} 9$ \\
\hline Code in TTD & $\mathbf{m c m}$ & $3,3,3,3,4,4 \mathrm{~L} 41$ & & \\
\hline
\end{tabular}


Not all atoms $\mathrm{H}$ of $\mathrm{H}_{2} \mathrm{O}$ were localized in the structure of FELRIA (all $\mathrm{H}_{2} \mathrm{O}$ molecules lack $\mathrm{H}$ ) and SAXDON (two symmetrically distinctive atoms $\mathrm{O}$ involved in 8-membered ring in the layer lack H) (Figure 3). However, it is not difficult to affirm the presence of $\mathrm{H}$-bonds $\mathrm{H}_{2} \mathrm{O} \ldots \mathrm{OH}_{2}$ by the short distances O...O. Despite the localization of all $\mathrm{H}$ atoms in EHUJEY, there is no binding proton between two atoms $\mathrm{O}$ which form $\mathrm{H}$-bond as donors with the tertiary amino group of organic molecule.

The reason for this is the location of the centre of $\mathrm{O} . . . \mathrm{O}$ in the inversion centre. Let the stoichiometry of a hydrate be $\mathrm{Y} \cdot n \mathrm{H}_{2} \mathrm{O}$, where $\mathrm{Y}$ is the organic component, and the protic excess $P$. Then $P \cdot n \cdot Z^{\prime}$ is the number of excess protons, and $(2-P) \cdot n \cdot Z^{\prime}$ is the number of binding protons, per asymmetric unit. If $\mathrm{O}$ atoms do not occupy specific positions (site symmetry higher than 1) and are not disor- dered, then $P \cdot n \cdot Z^{\prime}$ and $(2-P) \cdot n \cdot Z^{\prime}$ are both integers or non-integers. Excess protons cannot occupy specific positions, otherwise the adjacent $\mathrm{O}$ would occupy the same position (generally a rotational axis), therefore when $P \cdot n \cdot Z^{\prime}$ is a non-integer, some excess protons are disordered. On the contrary, binding protons cannot be disordered, otherwise adjacent atoms $\mathrm{O}$ would be also disordered. Consequently, when $(2-P) \cdot n \cdot Z^{\prime}$ is a non-integer, some binding protons occupy specific positions. In about $60 \%$ of monohydrates with dimers $\left(\mathrm{H}_{2} \mathrm{O}\right)_{2}$ binding proton occupies an inversion centre, and the excess protons are not localized [14]. In EHUJEY the organic molecule coordinates both excess protons of $\left(\mathrm{H}_{2} \mathrm{O}\right)_{\infty}$, but the calculated protic excess is $3 / 8$ instead of $1 / 4$ as it should be in this case. The lacking binding proton in the inversion centre is responsible for this inconsistency.

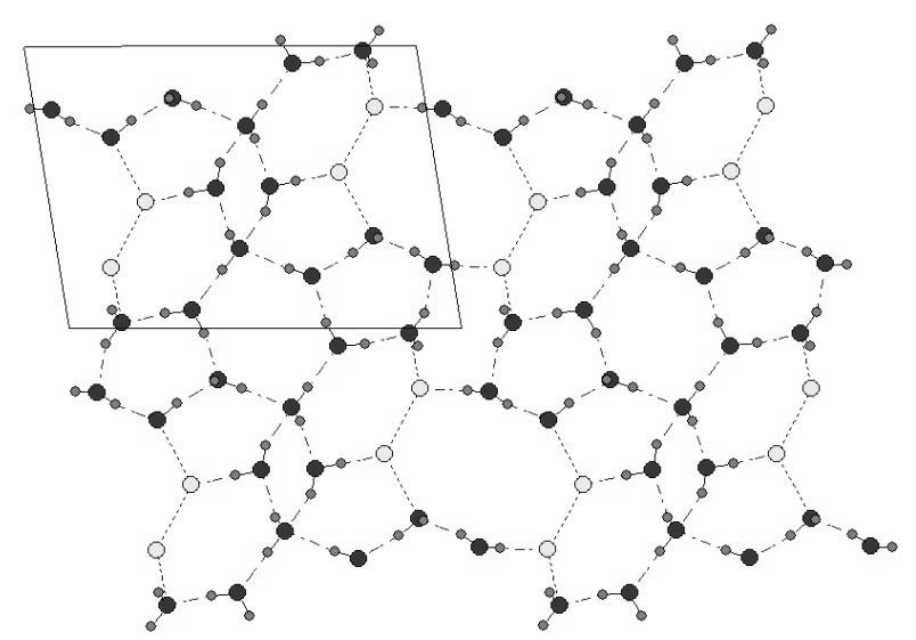

Fig. 3. A fragment of the net $\left(\mathrm{H}_{2} \mathrm{O}\right)_{\infty}$ in $\mathrm{SAXDON}$, projection along [001]. Atoms $\mathrm{O}$ lacking protons are coloured in light gray.
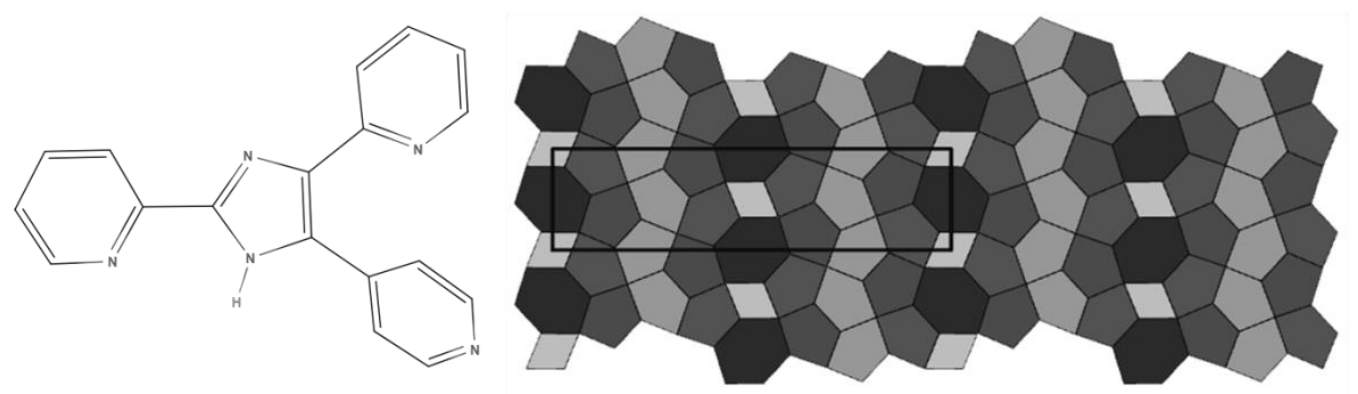

Fig. 4. Idealized aqueous net and the structural unit of organic host in FELRIA. 

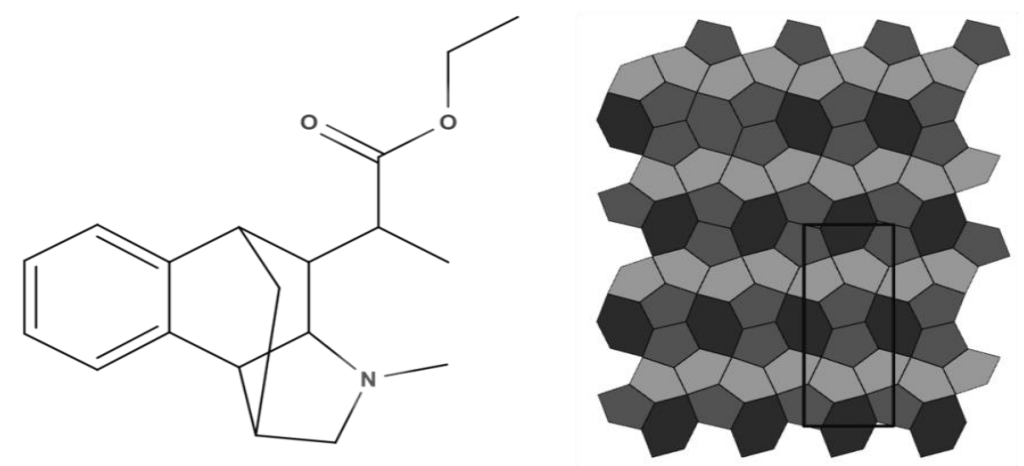

Fig. 5. Idealized aqueous net and the structural unit of organic host in EHUJEY.
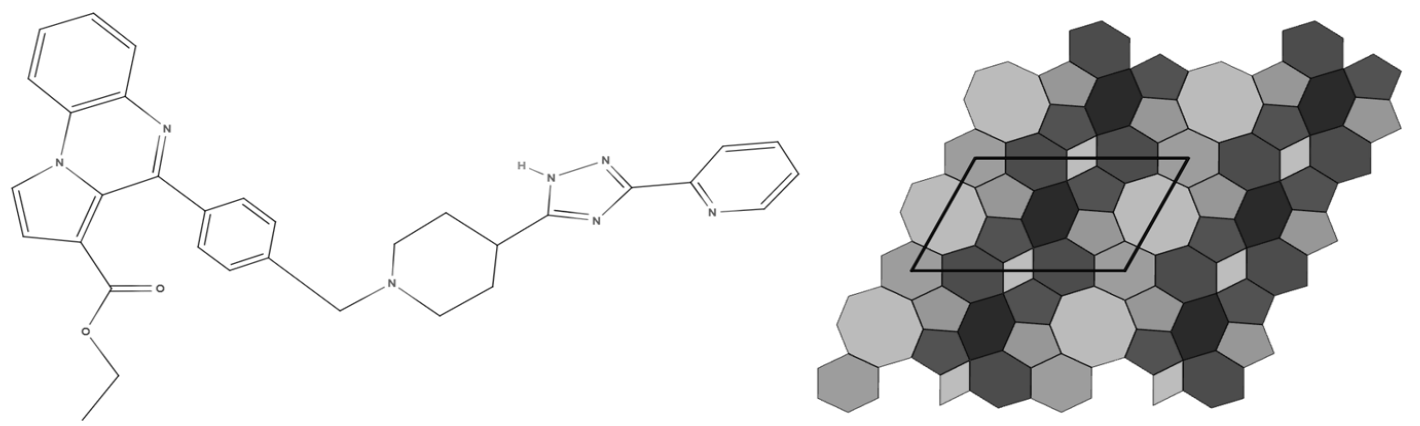

Fig. 6. Idealized aqueous net and the structural unit of organic host in SAXDON.

In Figure 4-6 the results of calculation of idealized symmetry of detected layers are presented. All nets are planar and projected onto a plane without intersection of edges. The optimized crystal system remains unchanged for all the nets: rectangular for EHUJEY and FELRIA, opaque for SAXDON. The vertex transitivity also remains unchanged and is equal to the number of symmetrically independent water molecules in the layer. Information entropy also remains unchanged. It means impossibility of generating any homeomorphic net of a smaller number of non-equivalent molecules. The average size of $\mathrm{H}_{2} \mathrm{O}$ ring for FELRIA, EHUJEY, SAXDON is 5, 5.2 and 5.6, respectively, and the protic excess increases in this series. In each structure all excess $\mathrm{H}$ are bound by the organic molecule. For example, in SAXDON each of the two non-equivalent organic molecules $\left(Z^{\prime}=2\right)$ forms four bonds as $\mathrm{H}$-acceptor with water molecules, and the same number of excess protons is contained in the asymmetric unit: $9 \cdot 4 / 9+2 \cdot 2=8$. Nets in
EHUJEY and FELRIA consist of fragments of Cairo tiling. In SAXDON a true part of Cairo tiling alternates with a tape of 4- and 6membered rings, which itself is also extremely popular in organic crystal hydrates [8]. In EHUJEY the topology of Cairo tiling is perturbed by 6-membered rings instead of 5membered (Figura 3a). The quantity of structural information $I_{G}$ and $I_{G, \mathrm{n}}$ increases from EHUJEY to FELRIA and then to SAXDON. Recently, it was shown [30] that more than half of lattice energy (about 55\%) in crystalline hydrates of such type falls at layers $\left(\mathrm{H}_{2} \mathrm{O}\right)_{\infty}$, so that the topology of these layers is likely to be the main driven force for host molecular arrangement and the crystal structure as such.

\section{Conclusion}

In comparison with the most primitive prototype of layers $\left(\mathrm{H}_{2} \mathrm{O}\right)_{\infty}$, the Cairo tiling mom, novel layers have more transitivity, more cyclomatic number, and more information both per atom $\mathrm{O}$ and after normalization. This is likely to be reasoned by the in- 
creased complexity of the host unit (an organic molecule). To conclude, novel topological approaches implemented in Topos Pro, Gavrog, etc., allow one to detect unusual and complex types of supramolecular motifs with known structural data. Since misdescribed topologies are likely to be found in crystal structures refined earlier, a retrospective analysis throughout structural databases would be a reasonable option for any future study in this field.

\section{References}

1. Stahly G.P. Diversity in Single- and MultipleComponent Crystals. The Search for and Prevalence of Polymorphs and Cocrystals. Cryst. Growth Des. 2007. V. 7. No 6. P. 1007-1026.

2. Pudipeddi M., Serajuddin A.T.M. Trends in Solubility of Polymorphs. J. Pharm. Sci. 2005. V. 94. No 5. P. 929-939.

3. Hulme A.T., Price S.L. Toward the Prediction of Organic Hydrate Crystal Structures. J. Chem. Theory Comput. 2007. V. 3. No 4. P. 1597-1608.

4. Boothroyd S., Kerridge A., Broo A. et al. Why Do Some Molecules Form Hydrates or Solvates? Cryst. Growth Des. 2018. V. 18. № 3. P. 1903-1908.

5. Pirzadeh P., Beaudoin E.N., Kusalik P.G. Structural evolution during water crystallization: Insights from ring analysis. Chem. Phys. Lett. 2011. V. 517. No 4. P. 117-125.

6. Banaru A.M., Banaru G.A. Proton redundancy in planar aqueous networks $\left(\mathrm{H}_{2} \mathrm{O}\right)_{\infty}$. Moscow Univ. Chem. Bull. 2012. V. 67. No 1. P. 5-7.

7. Infantes L., Fábián L., Motherwell W.D.S. Organic crystal hydrates: what are the important factors for formation. CrystEngComm. 2007. V. 9. No 1. P. 65-71.

8. Infantes L., Motherwell S. Water clusters in organic molecular crystals. Cryst Eng Comm. 2002. V. 4. No 75. P. 454-461.

9. Banaru A.M., Slovokhotov Y.L. Crystal hydrates of organic compounds. J. Struct. Chem. 2015. V. 56. No 5. P. 967-982.

10. Banaru A.M., Banaru G.A. Cairo tiling and the topology of layered hydrates. Moscow Univ. Chem. Bull. 2011. V. 66. No 3. P. 159.

11. Zheligovskaya E.A., Malenkov G.G. Crystalline water ices. Russ. Chem. Rev. V. 75. No 1. P. 57-76.

12. O'Keeffe M., Peskov M.A., Ramsden S.J., Yaghi O.M. The Reticular Chemistry Structure Resource (RCSR) Database of, and Symbols for, Crystal Nets. Acc. Chem. Res. 2008. V. 41. № 12. P. 1782-1789.

13. The Samara Topological Data Center, https:// topcryst.com/.

14. Banaru A., Slovokhotov Y.L. On the topology of layered motifs (H2O)œ. CrystEngComm. 2010. V.
12. No 4. P. 1054-1056.

15. Banaru A. On water nets L4 $(x) 6(y)$. Cryst Eng Comm. 2011. V. 13. No 1. P. 212-214.

16. Blatov V.A. Methods for topological analysis of atomic nets. J. Struct. Chem. 2009. V. 50. No 1. P. 160-167.

17. Rzepiński P., Nowosielska B., Cyrański M.K. et al. Kosmotropic Behavior of 3-Pyrroline during Crystalline Hydrates Formation. Cryst. Growth Des. 2019. Vol. 19, № 8. P. 4721-4730.

18. Blatov V.A., Shevchenko A.P., Proserpio D.M. Applied Topological Analysis of Crystal Structures with the Program Package ToposPro. Cryst. Growth Des. 2014. V. 14. No 7. P. 35763586.

19. Delgado-Friedrichs O. http://www.gavrog.org.

20. Delgado-Friedrichs O., O'Keeffe M. Identification of and symmetry computation for crystal nets. Acta Crystallogr. Sect. A. 2003. V. 59. No 4. P. 351-360.

21. Sunada T. Lecture on topological crystallography. Japan J. Math. 2012. V. 39. No November 2011. P. 1-39.

22. Blatov V.A., O'Keeffe M., Proserpio D.M. Vertex-, face-, point-, Schläfli-, and Delaneysymbols in nets, polyhedra and tilings: Recommended terminology. Cryst Eng Comm. 2010. V. 12. No 1. P. 44-48.

23. Krivovichev S. V. Which inorganic structures are the most complex? Angew. Chem. Int. Ed. 2014. V. 53. No 3. P. 654-661.

24. Schwarzenbach D. Structure of Piperazine Hexahydrate. J. Chem. Phys. 1968. V. 48. No 9. P. 4134-4140.

25. Beukemann A., Klee W.E. Minimal nets. Zeitschrift fur Krist. 1992. V. 201. No 1-2. P. 37-51.

26. Banaru A., Banaru D. Overlooked Types of Layered Molecular Hydrates Over the Past Decade. Struct. Chem. 2020. Vol. 31, № 4. P. 1449-1455.

27. Schweighauser L., Bodoky I., Kessler S.N. et al. Bidentate Lewis Acid Catalyzed Domino DielsAlder Reaction of Phthalazine for the Synthesis of Bridged Oligocyclic Tetrahydronaphthalenes. Org. Lett. 2016. Vol. 18, № 6. P. 1330-1333.

28. Behera N., Manivannan V. Selective Recognition of $\mathrm{Zn}^{2+}$ Ion Using 2,4-bis(2-pyridyl)-5-(4-pyridyl)imidazole: Spectra and Molecular Structure. Chemistry Select. 2016. V. 1. No 13. P. 4016-4023.

29. Desplat V., Vincenzi M., Lucas R. et al. Synthesis and Antiproliferative Effect of Ethyl 4-[4-(4Substituted Piperidin-1-yl)]benzylpyrrolo[1,2a]quinoxalinecarboxylate Derivatives on Human Leukemia Cells. ChemMedChem. 2017. V. 12. No 12. P. 940-953.

30. Socha P. et al. Intermolecular interactions in hydrates of 4-methylpiperidine and 4-chloropiperidine - a structural and computational study. Cryst Eng Comm. 2021. V. 23. P. 1251-1262. 


\section{НЕОБЫЧНЫЕ ТИПЫ СЛОИСТЫХ ОРГАНИЧЕСКИХ КРИСТАЛЛОГИДРАТОВ}

\section{А.М.Банару, Э.С.Мамедов}

В молекулярных кристаллогидратах при высоком содержании кристаллизационной воды формируются бесконечные сети $\mathrm{H}_{2} \mathrm{O}$... $\mathrm{OH}_{2}$ либо конечные фрагменты таких сетей. Как правило, сети содержат 5- и 6-членные циклы $\left(\mathrm{H}_{2} \mathrm{O}\right)_{n}$. Обнаружены и исследованы совершенно новые топологические типы слоистых органических кристаллогидратов среди структур, включенных в Кембриджский банк данных в 2009-2019 гг. Обнаруженные сети депонированы в Topological Types Database. Описаны топологические характеристики новых сетей. B частности, максимально возможная симметрия, информационные индексы, транзитивность сетей по вершинам, ребрам и граням.

Ключевые слова: кристаллогидрат, топология, сложность, Н-связь, сеть, клатрат, кристаллическая структура, рентгеноструктурный анализ, молекулярный агломерат, симметрия, Каирская мозаика, анализ данных.

\section{LAYLI UZVI KRISTALLOHIDRATLARIN QEYRİ-ADİ NÖVLORİ}

\section{A.M.Banaru, E.S.Məmmədov}

Yüksək miqdarda kristllaşma suyu olan molekulyar kristalhidratlarda sonsuz $\mathrm{H}_{2} \mathrm{O} \ldots \mathrm{OH}_{2}$ şəbəkələri və ya bu cür şəbəkələrin sonlu parçaları meydana gəlir. Tipik olaraq, şəbəkələr 5 və 6 tərəfli dövrləri $\left(\mathrm{H}_{2} \mathrm{O}\right)_{n}$ ehtiva edir. 2009-2019cu illərdə Cambridge Məlumat Bankına daxil olan strukturlar arasında təbəqəli üzvi kristal hidratların tamamilə yeni topoloji növləri aşkar edilmiş və araşdırılmışdır. Aşkar edilmiş şəbəkələr Topoloji növlər bazasında yerləşdirilmişdir. Yeni şəbəkərin topoloji xüsusiyyətləri, xüsusilə də mümkün olan maksimum simmetriya, məlumat indeksləri, şəbəkələrin təpələr, kənarlar və üzlərə qörə keçidliyi təsvir edilmişdir.

Açar sözlər: kristallohidrat, topoloji, mürəkkəblik, H-rabitə, şəbəkə, klatrat, kristallik quruluş, rentqenquruluş analiz, molekulyar aqlomerat, simmetriya, Qahiro mozaikası, molumatlarin analizi. 